\title{
A REVIEW ON DEVELOPING BALAGHAH TEST IN HIGHER LEARNING INSTITUTION
}

\author{
SHUHAIDA HANIM MOHAMAD SUHANE*, KASEH ABU BAKAR, \& MD. NOR \\ ABDULLAH
}

\begin{abstract}
This article reviews on the administration of teaching Balaghah at higher institutions in Malaysia was done to: (1) identify past research on the teaching and learning of Balaghah in Malaysia, (2) locate gap within related research on teaching and testing Balaghah in Malaysia, and (3) analyse new issues regarding teaching and testing of Balaghah which can provide references in the future. This review used a qualitative method, involving data retrieval and content analysis. Among the analyzed documents include journal articles, dissertation, books, working papers and proceeding seminars. The result shows that a balaghah testing and assessment is not given adequate emphasis, and the balaghah test is still lack of application aspects. Based on this finding, the recommendation of this review is to develop an instrument as an model for Balaghah Test in Higher Education Level (UPBal).
\end{abstract}

Keywords: Developing; Balaghah test; Higher learning institution

\section{INTRODUCTION}

Balaghah is a critical subject within the field of teaching and learning in the Arabic language. In the context of teaching and learning, Balaghah is the knowledge of language structure - third after the knowledge of syntax (nahu) and morphology (saraf). The knowledge of Balaghah is also known as the knowledge of rhetorics, which is the knowledge to understand hidden meaning during the sentence construction and the variety of uslub and diverse Arabic language styles. The essence of the knowledge of Balaghah is based on the exploration of Quranic meaning, stylistics, and miracle through the observation of a variety of structures in syntax, sentence construction and stylistics, which is unique and different from the common sentences. Balaghah in general, means, word. Al-Balaghat refers to the meaning of fine, beautiful, good, and serene as well as to arrive at a point. Balaghah also refers to the meaning of eloquent and proficient in the Kamus Dewan the fourth edition (2010). Its root word balagha (بلغ), as pronounced by al-Hasyimi in his manuscript JawÉhir al-Balaghah, the word balagha means "arrived", for example, in the sentence بلغ فلان مر اده, which means a person who achieves his desired goal (Abdul Rahman Hassan 2007). In Mu'jam Lisanul Arab, Ibnu Manzur mentioned which means "meaning or desire achieved", the word (البُلْغ بالثيء) on the other hand, means fasahah, which is proficient. Whereas (رجل بليغ) means a man who is proficient in his oratory, fluid in his expression, which is his ability to express himself with precision, both emotionally and mentally. While al-kalam al-baligh (الكلام البليغ) are beautiful words, which affects the heart or appropriate words in line with the speaker's meaning and context (يطابق (الكلام على مقتضى الحال Balaghah also means: "The precision of expression is at par with the requirement of contextual meaning and usage (Syaid Ahmad al-Hasymy, t.th). Ali al-Jarim dan Mustafa Amin (1984) defined the knowledge of Balaghah as "conveying meaning with clarity, using precise and eloquent expression, as well as giving great impact to another". 
Al-Qazwiniy, on the other hand, mentioned about balaghat al-mutakallim which is the talent and ability to construct beautiful words. While balaghat in speech refers to guarded words from misplacing desired meaning as well as differentiating between eloquent words and otherwise. Abd al-Qahir al-Jurjaniy in his manuscript Dalailul I'jaz mentioned about the fine line between al-balaghat, al-fasahat, al-bara'at, al-bayan, which altogether convey words that contain beautiful and good connotations, as well as expressing the intended portrayal in the best of expression or words, thus injecting the beautiful message into the listener's soul in line with the listener's context.

The position of the knowledge of Balaghah as the Knowledge of language structure is third after the knowledge of nahu and saraf, which is illustrated in the following figure:

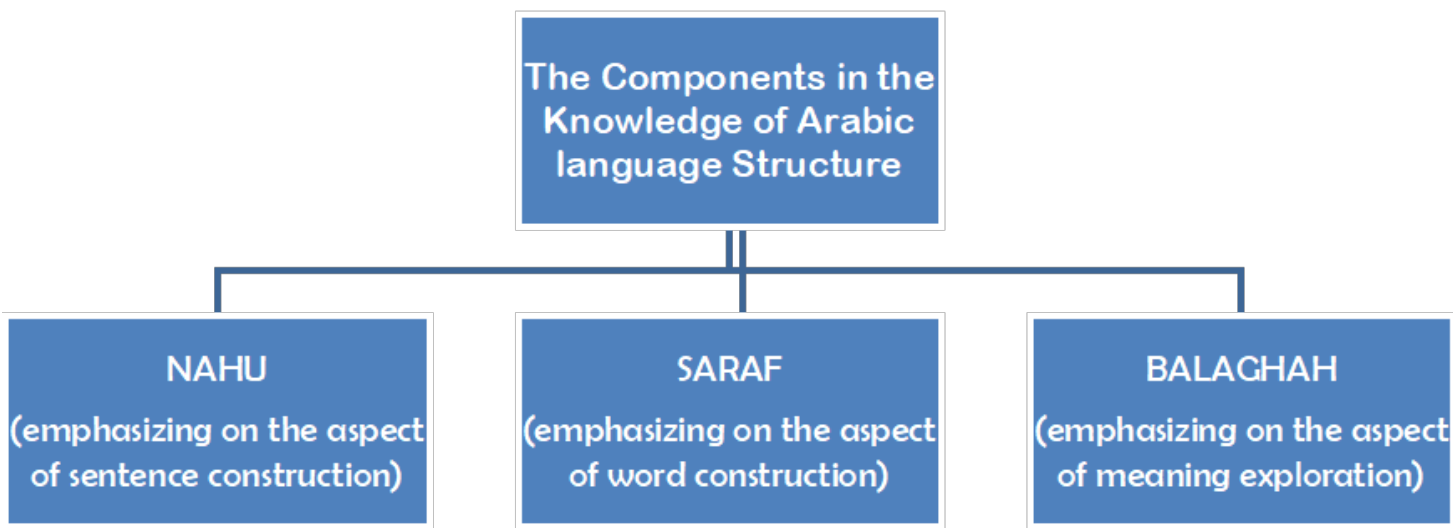

Figure 1. The Components in the Knowledge of Arabic Language Structure.

In approaching the teaching of Arabic language and its knowledge, Balaghah is assumed to be a knowledge in the form of methodology or formula to understand the poetical and the loftiness of meaning in Quranic verses, as well as Arabic aesthetical literary values. Badri Najib Zubir (2008) highlighted that the knowledge of Balaghah is a medium or instrument of assessment and description of Quranic verses from the aspect of describing aestheticism and explaining the loftiness of meaning. This is mentioned in his studies on the implementation of the knowledge of Balaghah in the translation of al-Kassyaf by azZamakhsyari.

The knowledge of Balaghah is also assumed as the knowledge to assess and measure students' level of speech quality as well as to identify aesthetic angle in each of the spexakers' words (Falah Soleh 2015; Imran Jasim et al. 2013; Ratib Qasim et al. 2009; Ali A. Madkur 2010; Mohsen A. Atiyah 2007; Mahmood Kamil et al. 2003). Students should not only utter eloquent and aesthetical words but should also be able to appreacite and uncover hidden meaning, especially those included in the Al-Quran. This talent and skill are retrieved from effective learning on the knowledge of Balaghah which covers the methods and appreciation of Quranic verses, beautiful expressions from the hadith, or prose, as well as wholesome effort to understand and appreciate them to the best possible (Shuhaida et al. 2017).

Evidently, the knowledge of Balaghah is an important knowledge for students to master the waysof understanding the beauty and miracles of Quranic verses, besides serving as a medium to be engrossed with aesthetic taste and Arabic literature as well as a means to learn in a constructive way and to express beautiful and good words, which trigger the soul. 


\section{METHODOLOGY}

This review is qualitative in nature, which involves content analysis and the use of documents related to the topic studied. According to Chua Yan Piew (2011), a literature review is an effort of critically and systematically creating references on documents containing information, ideas, data, and methods of retrieving related information on the research topic. The main purpose of this literature review is to employ a scientific perspective onto the present study, besides providing information from legitimate sources related to the topic and research construct. Nor Aisyah Buang (2010) summarized that the writing of a literature review should employ three basis aspects, which are introduction, content, and conclusion. Meanwhile there are two models to be used in the methodology used in a literature review, which are thematic review and study by study review. Besides that, Buang also listed down the characteristics of a good literature review, which are its summative role of past research by providing critical and evaluative assessment. Its enormous yet in-depth scope, its clear and precise writing, as well as its firm and consistent stand.

Some of the characteristics of a weak literature review is its descriptive writing on each reference, its nature of collecting information without any critical analysis, its narrow scope of review, its blurry and lengthy content, its inconsistent delivery, and overreliance of secondary resources. Method of data analysis in a literature review is conducted using descriptive analysis as according to the determined themes in researching the teaching of Arabic Balaghah along with a research on test constructing and the administration of Balaghah assessment. In this review, the researchers conducted a literature analysis on the reading materials and elaborate the review as according to the organized themes where a table is included for clarity.

\section{RESULTS AND DISCUSSION}

\section{Past Research on the teaching and learning of Balaghah in Malaysia}

Balaghah education in Malaysia underwent several stages and processes of development starting from the level of secondary education to the level of higher learning institution such as diploma, undergraduate, postgraduate which started with the earliest education in Malaysia which is Pendidikan Pondok is the founding system of madrasah in the early 20th century, which establishes the present school education. According to Abdullah (2006), Balaghah education started with the establishment of Islamic education in monasteries, which indirectly included the subject of tafsir and hadith, that required discussions over the beauty of Quranic Balaghah verses or hadith. In Abdul Hakim's analysis, Arabic Balaghah education in Malaysia began with the establishment of Pendidikan Pondok in the country, where the subject was first introduced as an official subject in the curriculum for the establishment of monasteries. Among the earliest Pendidikan Pondok are Madrasah al-Mashoor in Pulau Pinang which was established in 1914, while Madrasah al-Saadiyah al-Salihiyyah in the same year in Perak. The third, Madrasah al-Muhammadiah in Kota Bharu, which was established in 1917, followed by Maktab Mahmud in Kedah, in 1937. All four madrasah are pioneers of Balaghah education in Malaysia, which was then introduced as an isolated subject as compared to the subject of Islamic religious and Arabic language.

In Arab Saudi, the establishment of Balaghah knowledge began indirectly before the period of Abdul Qahir al-Jurjani $(471 \mathrm{H})$, where the study of Quranic miracles begun. Among the most outstanding miracles during that period is al-i'jaz al-bayani or known as Quranic balaghah poetic miracle. The period of Abdul Qahir al-Jurjani witnessed the initiation of Balaghah knowledge as a separate discipline that studies and explores the beauty of Balaghah 
and Quranic miracles from the perspective of language poetics. Al-Jurjani collected previous research by scholars of language and Arabic balaghah where he explained and critically analysed them that he was then known as the founder of Balaghah knowledge and al-I'jaz alBayani in al-Quran. Through his critical research and analysis, al-Jurjani developed new findings, which was entirely novel as compared to earlier research. In fact, his research was assumed to be excellent, comprehensive, and novel as compared to previous scholars nor those who proceeded him, who innovated, critically analysed, and read better in comparison to alJurjani (Nasreldin 2002). Nevertheless, his research is a continuum from others (e.g).

Based on previous research on Quranic miracles which later developed into the initiation of Balaghah knowledge, it is observable that the knowledge underwent numerous stages and challenges in its development which was a century-long struggle. Hence, the process of teaching and learning Arabic Balaghah is a maturing process of turning a knowledge into high cultured knowledge, which is obviously the case at present since it plays a big role, not only in the language context and Islamic world, but also most predominantly at defending the language of Quran as the words of Allah are miracles. Allah says that He will continuously protect the Quran until the Hereafter, which is means "It is We who bestow the Quran, and it is We who will keep it protected". As Allah promises to continuously preserve the Quran, He will ensure the longevity of Quranic language. The language is inseparable from the Kalamullah, and there are bound to be enemies of Islam who continuously concoct efforts to destroy its purity, tarnish its beauty. At the same time, there will also scholars and pious clergies who are steadfast at protecting its sanctity and uphold its language purity in the effort to harmonize its linguistic beauty, which is marred by the orientalists, who study Arabic language in order to destroy it.

From the scope of teaching and learning of Arabic Balaghah, the researcher observed the lack of popularity of research on the scope of Balaghah education as compared to those conducted on other aspects of teaching and learning of Arabic language, such as nahu (Arabic syntax), saraf (Arabic morphology), the four aspects of language literacy (such as skills of reading, writing, listening, and speaking). In the curriculum of Balaghah education as outlined by scholars, there are four aspects needing attention and emphasis, which are:
a) teaching objectives
b) teaching modules
c) the methodology of teaching and learning
d) testing and assessment

These aspects form the research scope of the administered study in Balaghah education in Malaysia which can be observed in Table 1. Table 1 reviews a number of research on teaching and learning of Balaghah in Malaysia. One is done by Abdullah (2006) which was conducted on a group of secondary school students who are sitting for their STPM in order to identify and assess several aspects in the Balaghah education at the level of STPM including the determining of Balaghah teaching objectives, content syllabus for Balaghah teaching, the structure of Balaghah assessment, besides exploring problems encountered by teachers and students in the teaching and learning of Balaghah. The methodology used to obtain the data was a combination of qualitative and quantitative approach. Data was obtained from document and content analysis, teaching observations and surveys on students and teachers. Findings show that the determined teaching objectives for Balaghah remains unclear and too vaguely expressed, besides the fact that they are difficult to assess. While from the Balaghah evaluation aspect, the process of evaluation was not done comprehensively. It only measures the cognitive domain, which emphasizes on the level of knowledge, comprehension, and analysis, as well as abandoning the aspect of application in Balaghah. 
Table 1. Summary of Literature Teaching and Learning of Balaghah in Malaysia.

\begin{tabular}{|c|c|c|c|c|c|}
\hline Research & Sampling & Research design & Instrument & Findings & Themes \\
\hline $\begin{array}{l}\text { Abdullah } \\
\text { [41] }\end{array}$ & $\begin{array}{l}\text { Teachers and } \\
\text { STPM } \\
\text { students in } \\
\text { SMKA }\end{array}$ & $\begin{array}{l}\text { Combinational } \\
\text { (qualitative and } \\
\text { quantitative) }\end{array}$ & $\begin{array}{c}\text { Document } \\
\text { analysis, survey } \\
\text { among teachers } \\
\text { and students }\end{array}$ & $\begin{array}{l}\text { Students' level of } \\
\text { Balaghah proficiency } \\
\text { only covers aspects of } \\
\text { knowledge and } \\
\text { understanding, while } \\
\text { from the aspect of } \\
\text { constructing sentence } \\
\text { structure remains weak } \\
\text { where they fail to apply } \\
\text { Balaghah knowledge. }\end{array}$ & \multirow{3}{*}{$\begin{array}{l}\text { Objective } \\
\text { statement, } \\
\text { syllabus } \\
\text { content, } \\
\text { teaching } \\
\text { and } \\
\text { assessment }\end{array}$} \\
\hline $\begin{array}{c}\text { Muhammad } \\
\text { [42] }\end{array}$ & $\begin{array}{l}796 \text { STAM } \\
\text { students, } \\
\text { Form 6B in } \\
\text { SMKA }\end{array}$ & $\begin{array}{l}\text { Combinational } \\
\text { (qualitative and } \\
\text { quantitative) }\end{array}$ & $\begin{array}{c}\text { Document } \\
\text { analysis, survey, } \\
\text { Balaghah } \\
\text { proficiency test }\end{array}$ & \multirow[t]{2}{*}{$\begin{array}{l}\text { Students' interest and } \\
\text { readiness of Balaghah } \\
\text { learning obtain positive } \\
\text { responses and reactions } \\
\text { from the students. }\end{array}$} & \\
\hline $\begin{array}{l}\text { Muhammad } \\
\text { et al. [43] }\end{array}$ & $\begin{array}{c}320 \text { SPM } \\
\text { students from } \\
\text { SMA in Johor } \\
\end{array}$ & Quantitative & Survey & & \\
\hline $\begin{array}{c}\text { Raja } \\
\text { Sulaiman } \\
\text { [44] }\end{array}$ & $\begin{array}{l}200 \text { students } \\
\text { from higher } \\
\text { learning } \\
\text { institutions }\end{array}$ & Quantitative & $\begin{array}{c}\text { Survey, } \\
\text { Balaghah, } \\
\text { proficiency test }\end{array}$ & $\begin{array}{l}\text { Students were interested } \\
\text { to learn knowledge of } \\
\text { Balaghah; their level of } \\
\text { motivation is higher. } \\
\text { Nonetheless, their level } \\
\text { of proficiency is at low } \\
\text { and average level. }\end{array}$ & $\begin{array}{l}\text { Students' } \\
\text { motivation } \\
\text { and } \\
\text { mastery }\end{array}$ \\
\hline $\begin{array}{l}\text { Ab Halim } \\
{[45]}\end{array}$ & $\begin{array}{l}443 \text { STAM } \\
\text { students in } \\
\text { SMKA }\end{array}$ & $\begin{array}{l}\text { Quantitative and } \\
\text { qualitative }\end{array}$ & $\begin{array}{l}\text { Clause tests and } \\
\text { linguistic text } \\
\text { analyses }\end{array}$ & $\begin{array}{l}\text { Research findings show } \\
\text { that textbook readability } \\
\text { for Balaghah at } \\
\text { secondary school level } \\
\text { does not match with } \\
\text { students' level of } \\
\text { reading skills. }\end{array}$ & $\begin{array}{l}\text { Textbook } \\
\text { readability } \\
\text { for } \\
\text { Balaghah } \\
\text { (syllabus) }\end{array}$ \\
\hline $\begin{array}{l}\text { Sopian et } \\
\text { al. }[46]\end{array}$ & $\begin{array}{c}30 \text { SPM } \\
\text { students from } \\
\text { SMKA and } \\
\text { SABK }\end{array}$ & Qualitative & Pilot study & $\begin{array}{l}\text { Students' perception at } \\
\text { secondary level on } \\
\text { knowledge of Balaghah } \\
\text { is still negative; they are } \\
\text { still not interested, lack } \\
\text { of awareness on the } \\
\text { significance and purpose } \\
\text { of learning this } \\
\text { knowledge, as well as } \\
\text { have problems to } \\
\text { acquire the knowledge. }\end{array}$ & $\begin{array}{l}\text { Students' } \\
\text { perception } \\
\text { and } \\
\text { mastery }\end{array}$ \\
\hline
\end{tabular}

Students from higher Ab Halim learning et al. [47] institutions in the east coast of Malaysia
Ability to read al-

Balaghah al-Wadihah is at a disappointing level. Students' ability to understand the book is at ability a worrying level.
Textbook 


\begin{tabular}{|c|c|c|c|c|c|}
\hline Sopian [48] & $\begin{array}{c}246 \text { students } \\
\text { from SMKA } \\
\text { and SABK }\end{array}$ & $\begin{array}{c}\text { Qualitative and } \\
\text { Quantitative }\end{array}$ & $\begin{array}{l}\text { Survey, test, } \\
\text { interview, and } \\
\text { document } \\
\text { analysis }\end{array}$ & $\begin{array}{l}\text { Students' interest and } \\
\text { mastery of Balaghah at } \\
\text { secondary level is at an } \\
\text { average level; while at } \\
\text { the assessment level, } \\
\text { they have problems to } \\
\text { answer questions in the } \\
\text { form of textual } \\
\text { appreciation and prefer } \\
\text { to answer questions that } \\
\text { require memorization. }\end{array}$ & $\begin{array}{l}\text { Aspects of } \\
\text { interest, } \\
\text { mastery } \\
\text { and } \\
\text { assessment }\end{array}$ \\
\hline $\begin{array}{l}\text { Mohamad } \\
\text { Suhane et } \\
\text { al. [49] }\end{array}$ & $\begin{array}{l}\text { Balaghah } \\
\text { lecturers at } \\
\text { Malaysian } \\
\text { public } \\
\text { universities }\end{array}$ & Qualitative & $\begin{array}{c}\text { Teaching } \\
\text { observations } \\
\text { and structured } \\
\text { interviews }\end{array}$ & $\begin{array}{l}\text { University lecturers are } \\
\text { seen to be more creative } \\
\text { at using teaching } \\
\text { techniques and } \\
\text { strategies, which are } \\
\text { effective at drawing } \\
\text { students' interest, } \\
\text { despite the existing trend } \\
\text { of teaching - teacher- } \\
\text { centred, discouraging } \\
\text { students from } \\
\text { participating and two- } \\
\text { way communication. }\end{array}$ & $\begin{array}{l}\text { Teaching } \\
\text { strategies }\end{array}$ \\
\hline $\begin{array}{l}\text { Mohd } \\
\text { Rafian et } \\
\text { al. [50] }\end{array}$ & $\begin{array}{c}236 \\
\text { undergraduate } \\
\text { s from } \\
\text { Bachelor of } \\
\text { Arabic } \\
\text { language } \\
\text { offered in } \\
\text { public } \\
\text { universities }\end{array}$ & Quantitative & Survey & $\begin{array}{l}\text { Five items from the } \\
\text { Module domain of } \\
\text { desired developing } \\
\text { module which is needed } \\
\text { and Balaghah in } \\
\text { students' learning in the } \\
\text { syllabus are at the } \\
\text { highest level }\end{array}$ & $\begin{array}{c}\text { Module } \\
\text { developing } \\
\text { and } \\
\text { Balaghah } \\
\text { syllabus }\end{array}$ \\
\hline
\end{tabular}

\section{(2) Past Research on Developing and Constructing Balaghah Test}

Testing and assessment are two important concepts which are inseparable in education. Ariffin (2008) defined testing as a process of measuring students' proficiency performance in any classroom discipline using tests. According to Ahmad and Awang (2008), testing carries a specific definition with a narrower scope as compared to measurement, which is a process of submitting a set of standardized questions which requires answering, or a set of systematic instruments or procedures used in order to measure sample's behaviour or changes of an individual or student. Abd Ghafar (2011) on the other hand, defined testing as a systematic tool or procedures used to measure any sample's behaviour, besides determining students' achievement in any field.

Nordin (2005) classified testing into several types as according to its purpose and way of assessing the test result. Testing can be divided into different purposes which are achievement and aptitude test. Meanwhile types of testing as according to testing results can be divided into normal reference and criterion reference test. Ariffin (2008) further elaborated on the purpose of testing which are integrative and differentiative testing. Integrative testing is used for developing and improving curriculum, thinking ability, general skills, attitude, and value, while differentiative testing is used to identify students as according to different 
profession, skills, and class. This means, testing allows teachers to improve curriculum and reorganize teaching strategies in order to improve teaching activities.

In outlining the objective of testing which is to produce evidence that can be used to diagnosed teaching and learning in classrooms, Ariffin (2008) also provided an illustration of relationship between testing, measurement, and evaluation. This relationship is shown in the Figure 2.

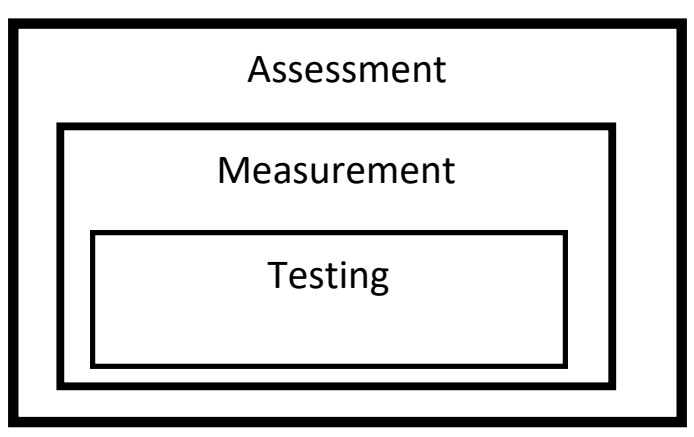

Figure 2. Relationship between Testing, Measurement and Evaluation

Based on Figure 2, Ariffin elaborated how measurement provides tools to determine students' ability as according to certain principles. Testing, on the other hand, is methods or procedures used in the written form. Both methods are equally important and depend on each at assessing students' achievement.

In short, testing is a process that occurs in measurement. It is a tool or instrument used in assessment. Measurement is represented in Figure 3.

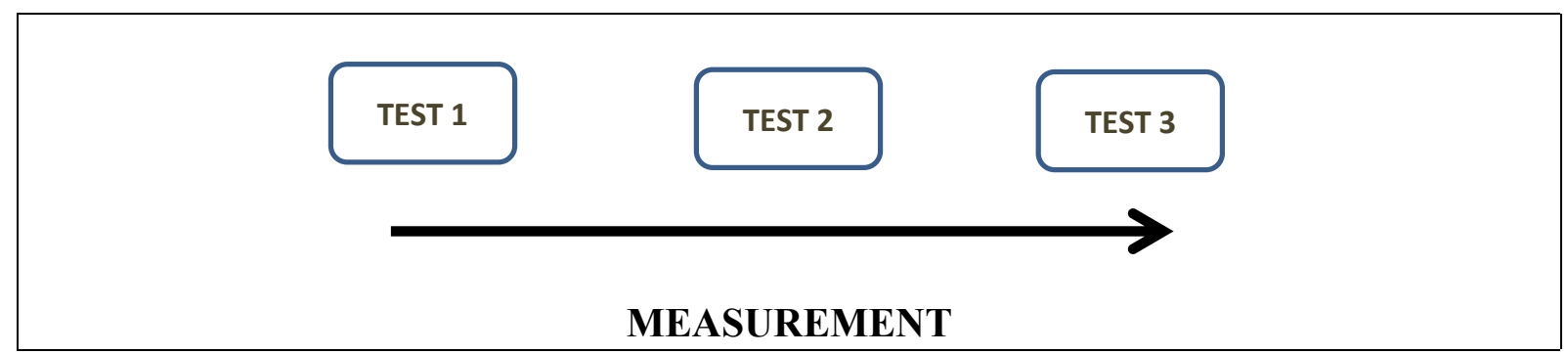

Figure 3. Comparison Between testing and measurement.

In the aspect of Balaghah, scholars place importance in the effort of constructing at the level of tazawwuq adabi which is Arabic artistic and literary taste within students who are undergoing the knowledge of Balaghah. Meanwhile in the scope of testing and measurement in Balaghah, scholars emphasize on the aspects of testing and measuring at students' level of tazawwuq adabi. This level ought to be measured and evaluated continuously, whether in through measurement that is based on cognitive domain as according to Bloom's level of taxonomy (such as memorizing, understanding, applying, analysing, evaluating, and creating), or measurement that is based on theories or other sources. According to Ariffin (2008), the process of testing is important for its systematic nature that measures partially an individual's behaviour, besides functioning as a tool of measuring that aims to retrieve information on students' achievement from numerous angles such as cognitive, affective, and psychomotor. In testing Balaghah, tests are used as tools that enable teachers to organize and arrange the best strategies for students' Balaghah education, besides to measure students' Balaghah achievement or proficiency. 
The process of testing and measuring is part of the process in education. When formal process of education takes place, testing, measurement, and evaluation must also occur. All three terminologies have its own definitive meaning and scope. The process of testing onto students is a process of measurement and evaluation to measure students' level of mastery and weakness as well as a process to evaluate teaching, hence determine the best teaching strategies to be employed for a more effective process of education as well as achieving expected objectives in education. When the process of measurement happens, the process of teachers' evaluating students' level of mastery and weakness so to achieve teaching that enables the steering towards the appropriate direction and approach. The main purpose for the process of testing is to measure and evaluate students' level of mastery of the subject.

Some of the principles of testing as suggested by Brown (2010) is practicality, trustworthiness, validity, originality, and washback, which represents taught content. Banchman (1990) on the other hand, explained seven important components in testing which are trustworthiness, content validity, construct validity, originality, interactiveness, impactful and practicality. The process of test constructing also needs to undergo several processes or levels, which are:

1) Process of determining objectives

2) Process of selecting subject content or test content

3) Process of constructing table of testing specification

4) Process of expert validation

5) Process of validating using psychometric assessment

6) Process of testing reliability.

Some of research done in testing and measurement for Arabic language in Malaysian are done by Awang Mat Dahan (2012) and Abu Bakar (2012) focused more on constructing Arabic language proficiency test via online based on the use of informational technology. on the other hand, emphasized on the aspect of developing testing questions which are suitable with students' level and climate of different geography. Abdul Ghafar (2011) listed several tests; among which include placement tests, proficiency test and achievement test, and he also listed several tests and assessments based on different testing purposes. Among these are local assessment or pre-qualification, formative assessment, diagnostic assessment and summative assessment, and Abdul Ghafar continued explaining needed criteria or characteristics in any test, which are objectivity, validity, trustworthy and userability.

\section{Issues On Measuring and Testing Balaghah}

In the scope of measuring and testing Balaghah, scholars often criticize and highlight issues and problems regarding the teaching and learning of Balaghah. However, these criticisms remain distance and relevant authorities have yet to take actions. Among the issues are those regarding the deciding of the purpose and objectives, which are still uncertain in the Balaghah education, the issue of measurability and the assessment of the level of students' tazawwuq adabi (Arabic literary taste), the issue of Balaghah testing method which does not abide by the principles of testing and measurement, as recommended by experts. When the issue of Balaghah testing method is not handled well, there arises issues on testing Balaghah (which does not achieve its true purpose and objectives in teaching), students' achievement in exams (which does not represent their mastery in learning), as well as the exam-orientated teaching. 
The issue often occurs in the Balaghah testing and measurement which is the issue of constructing Balaghah questions which do not follow experts' specifications and testing methods which do not abide by the principles of testing and measurement as outlined by experts (Abd Rahman Hashimi et al. 2005; AH Abdullah et al. 2016). Therefore, Balaghah tests fail to be tools or medium to measure studets' level of development as well as enriching their potential. Tests or examinations held merely to penalize, instead of measuring or developing students' potential. Tests or in-classroom practices ought to aim towards assessing and measuring students' level of development and their weaknesses in a subject. In such case, Hassan Shahatah (1993) pointed out that test or in-classroom practices only help students to answer exam questions, not helping to shape language ability nor assist in developing Arabic aesthetic taste and literariness in themselves.

Findings from Abd Rahman Hashimi et al. (2005), on the other hand, showed that most teachers agree that conducted tests do not measure students' ability to do balaghah nor its level. Whereas it is through testing that teachers ought to be able to evaluate students' level of development and identify weak angles which thus consider actions to use appropriate strategies like enriching practices on aspects that students cannot master, doing drills and others. Meanwhile students are able to assess their level of development and evaluate their weaknesses, thus taking considerable actions to improve them by doing drills, asking questions on uncertain topics, doing group discussions and various other ways to improve mastery.

Abdul Rahman Hasyimi et al. (2005) also highlighted several characteristics of test questions which are its clarity, focus and measurability in order to achieve teaching objectives. Abdul Rahman also explained that tests are tools or medium of intermediary, which is not a purpose. Most teachers and students assume that tests are the ultimate purpose and determinant of one's success and failure in life, whereas it should be a medium for students to improve their aesthetic talent because language skills is one of the main aims. Tests should play a bigger role to encourage student to multiply their efforts and improve their skills in education. If tests truly serve as a reference instrument that determines strength and weakness that requires improvement, students will there make the effort to improve learning and teachers will work at increasing the quality of teaching. When testing methods fail to abide by the specifications, as forwarded by the experts, the conducted balaghah tests could not measure nor test the expected items. Abd Rahman Hashimi et al. (2005) also elaborated several problems occurring in the test designing, where administered tests emphasize on memorizing definitions and examples, explaining literary aestheticism remains memorizing-orientated, over-dependent of one type of question (which is the written form), the allocated time is insufficient to answer explanatory questions on the aesthetics of art and literature, questions in the tests are not suitable to students' level, the level of difficulty do not match as according to the expected quality.

Abdul Hakim (2016) also explained that Balaghah teaching, and assessment only focused on the level of knowledge, comprehension, and analysis. Similarly, issued test questions only measure on the level of students' knowledge, comprehension, and analysis without great effort to measure the level of application and Arabic literary taste development within the students. The level of analysis, on the other hand, is taken as the cognitive level, which is more dominant in testing. Nonetheless, when research on effectiveness was conducted, students were not able to analyse Quranic verses well and clearly (Anuar Sopian et al. 2013; Raja Hazirah 2012). Based on the resercher's observation, the process of analyzing Quranic verses or literary works taught in classrooms do not appear to be exploratory when approaching aestheticism. Rather, it focuses on teaching content and translating Quranic verses or merely to explain certain translated content of aesthetitc and literary works. This was 
reiterated by scholars on the purpose and methods of teaching Balaghah, which has slightly diverted from its original concept of exploring art and inculcating Arabic artistic and literary taste (Fathi Farid 1983; Abdul Rahim 1999; Azhar Muhammad 2006; Abdul Hakim et al. 2016; Shuhaida et al. 2017).

Based on past studies, teachers agreed that conducted tests were mainly developed based on trend or past question styles, without referring to the principles of measuring and testing as recommended by experts. Hence test questions lose its role as a tool to measure students' potential in Balaghah as a whole (Abd Rahman Hasyimi et al. 2005). From the researchers' observation, this occurs because of the lack of clarity in principles dan method of testing and measuring as part of teaching Balaghah, besides the problem of indefinite teaching purpose and objectives and unimproved syllabus of teaching Balaghah.

\section{b. Issues Regarding the Difficulty of Measuring Students' Level of Tazawwuq Adabi.}

Among the other discussed issues in the Balaghah testing and measurement is the difficulty to determine the level of development and construction of tazawwuq adabi within a student. Most scholars of the Arabic language education have decided that the construction of tazawwuq adabi is the purpose and main objective in the Balaghah teaching and learning (Falah Soleh 2015; Imran Jasim et al. 2013; Ratib Qasim et al. 2009, Ali A.Madkur 2010; Mohsen A. Atiyah 2007; Mahmood Kamil et al. 2003). The question is, how far are teachers and lecturers able to evaluate and assess tudents' level of tazawwuq adabi? Is there an available indicator to show that students have understood and appreciated the beauty and nobility of a Quranic verse or has experienced the poetics of a literary work? In this case, scholars believe teachers will experience problem and have some difficulty to measure the level of Arabic artistic and literary taste development as well as students' capacity level to perform balaghah. Scholars are divided in opinions when deciding on the most appropriate indicator to measure the level of tazawwuq adabi that they are still discussing on students' extent of Arabic artistic and literary appreciation, whether it can be measured using maudhui or wujdaani. Ali A.Madkur (2010) pointed out that there is no appropriate medium or indicator to measure a student's, unless if it is also done through tazawwuq adabi. A teacher or a lecturer should possess Tazawwuq adabi in order to assess and evaluate his student's level of tazawwuq adabi. Azhar Muhammad (2006) explained that, since men are distinguished in terms of their emotion and taste, the learning of aesthetic theories is difficult to be determined that it requires the learning of artistic comparison with another.

In a different situation, assessment experts have varying opinions. To them, the emotion or taste has its own indicator, which can be assessed and determined. In fact, Arabic artistic and aesthetic taste also has a measuring tool or indicator, which can be used as a guide to measure students' development of artistic taste. In his research to identify the most suitable indicator to measure tazawwuq adabi, Rusyd Tuaimah identified several guidelines to measure the level of tazawwuq adabi in a student, among which are the ability to explicate and extract main issues in a literary work, the ability to identify aesthetic values in a qasidah, the ability to appreciate poetics in a literary work, the ability to differentiate between the level of aestheticism between literary works, identifying important points in a literary work and other indicators to show a student's level of literary comprehension and appreciation. This is the indicator outlined by Rusyd Tuaimah in his research on tazawwuq adabi which is more specific and focused on the subject of pure Arabic literature. The researchers believe that for specifically the subject of Balaghah, there is indeed its own indicator to determine students' level of tazawwuq adabi, which is different from the subject of Arabic literature. 
This issue is also discussed in most subjects and field of knowledge. Based on past literature, the researchers observed that most scholars identified the teaching of Balaghah to be stagnant and exam-oriented, which causes students to be unable to absorb the concept of taste forming, the honing of balaghah skills, etc. (Littlewood 1987; Abdul Rahim 1999; Abdul Hakim 2008). Teaching based on exam-orientation often occurs as due to the incoherence between time allocation and syllabus or learning modul that needs to be taught. The researchers observed, unless proper and organised methodology of testing and assessment is employed, which follows experts' recommendation, issues regarding the exam-based teaching will not arise because the process of testing and examination actually contributes to positive reactions in order to help students improve their weakness in the subject. However, when testing or examination are not made to be medium or tools to improve students' potential, exam-based teaching will not only create problems to the students and teachers but also to the education sphere itself.

Besides that, among other issues regarding testing and measuring in Arabic Balaghah is students' inability to master the learning of Balaghah despite their high performance in the examination. The researchers believe this happens because of the objectives of test developing is not parallel and incoherent with its original purpose. Developed test questions were observed to have failed in measuring and testing what was expected to, hence not abling students to achieve their objectives. Apart than teachers' or lecturers' mistake of making tests as a platform to compare students' performance, causing the process of learning, and teaching to become stagnant and to exam-oreinted, whereas the testing process is conducted to develop students' talent to do balaghah (Kaseh Abu Bakar 2012). A research by Abd Rahman Hasyimi et al. (2005) showed that most teachers agreed that students' examination results do not portray their performance in classrooms and failed to help them develop their ability to learn the knowledge of Balaghah. Because of that, students are able to perform well in examinations despite their moderate level of mastery or lower (Raja Hazirah 2012; Anuar Sopian et al. 2015). Upon this realization, the researchers believe that the execution of testing at the higher learning should be improved from the aspect of focus and directions so that the process of testing and evaluation can be done to achieve its rightful purpose.

\section{SIGNIFICANCE AND RECOMMENDATION}

Analysing the literature review revealed that past studies on Balaghah education mainly focused on aspects such as Balaghah curriculum in Malaysia, problems encountered in the teaching of Balaghah, the level of mastery among Balaghah students, and teaching strategies and the development of teaching module for Balaghah. Samples in studies of Balaghah education also mostly concentrated secondary schools while studies at higher institution level were given lesser attention. Besides that, studies on Balaghah testing and measurement was not given adequate emphasis and has not been specifically administrated, especially at higher institution level in Malaysia.

Another observed matter from the literature review is the available types of testing models for Arabic language which were introduced at the level of higher learning for Arabic linguistics. Nonetheless, there is insufficient emphasis given in the aspect of Arabic Balaghah and literature. Research on assessment, evaluation, and measurement for the aspect of tazawwuq balaghi adabi, specifically the development of taste for arts that is, the fostering of artistry taste that should emphasize in literary or Quranic texts which are still underestimated. The researcher also observed that good measurement on the aspects of Arabic balaghah and 
literature has not been given sufficient attention in the field of Arabic language testing, as is the case with other language learning areas, especially English.

Reviewing the literature on Balaghah education in Malaysia and Balaghah test and implementation, besides the analysis of Balaghah teaching and learning issues, provided the researchers of the need to develop a Balaghah Test model and build a Balaghah Teaching Objective Inventory to discover new knowledge and improve the discipline of Arabic language. The Learning Objective Inventory complies with aspects as described in Bloom's Taxonomy, namely the cognitive domain, the affective domain, and the psychomotor domain. Researchers also noted on the need for improvements that enable the process of adapting this taxonomy in Balaghah's teaching. This process of refining Balaghah's teaching objectives is more focused, organized, and structured, as these are the root causes and problems of unresolved issues in the education of Arab Balaghah in Malaysia.

Among the highlights of this study are its significance to the teaching manpower of Balaghah, which provided models of questions in a Balaghah Test that specify criteria based the standards as outlined by the experts. The test is empirically tested, so the teachers are guided, providing them a compass of reference for building a good and balanced test question, thus making the process of testing and measurement as a guide for setting strategies in teaching Balaghah properly. Reviewing the literature on issues regarding testing and measurement of Balaghah also provided the researchers the opportunity to suggest for appropriate actions to be taken in order to address arising issues in this area. These are the suggested actions are administering several actions in this study, introducing the developing the Higher Education Test of Balaghah (UPBal).

The recommendation of this research is to develop an instrument for Balaghah Testing at the Malaysian Higher Learning or called as UPBal. This UPBal is a research instrument, developed as according to specification and starndard of expert testing and measurement at the higher education level. The process began with the developing of Inventory of Balaghah Teaching and Learning Objectives (i-Obal), which is arranged to become the foundation and construct at developing the model instrument of Balaghah Testing (UPBal). After undergoing the process of refinement, improvement and expert validation, the researchers then initiated the process of developing research item instrument which is the developing of items in Balaghah Testing (UPBaL). Developing these items was conducted after the researchers collected precise information on the criteria and specifications for developing tests at the level of higher learning as according to involved experts' recommendations.

The instrument model for Balaghah Testing (UPBal) employed the features of a psychometric scale where the criteria are based on standards outlined by experts (AH Abdullah 2015; Sahari Nordin 2005; Mokhtar Ismail 2002). Two features of a psychometric scale as outlined by experts, are its validity and reliability, and employing the principles of testing as mentioned by experts like Brown 2010. Principles like its objectivity, doability and assessibility were also considered when preparing the instrument for Balaghah Testing (UPBal). It is through the developing instrumen for Balaghah Testing (UPBal), Balaghah lecturers and teachers at the university and school levels will refer to it when administering an effective process of evaluating and assessing at the school and university level, besides obtaining a clear overview on the process of preparing good and balanced tests, as according to the features of psychometric recommended by the experts of testing and assessment.

The process of developing test items underwent several expected processes and procedures which are providing a brief description of the teaching and learning content. Balaghah at the level of higher education in higher instutions offers the subject of Balaghah as an evaluated subject. Upon completing the process of describing the content and syllabus of teaching Balaghah at the higher learning institutions in Malaysia, the researchers then administered the following process which is the process of developing and preparing testing 
items. This process began with preparing the Table of Testing Specification for Balaghah Testing (JSU of UPBal). The table arrangement was organized according to research constructs which was developed by referring to the inventory of Balaghah Teaching and Learning Objectives (i-Obal). Each item in the instrument was based on the objectives and learning outcome determined in the Table of Testing Specification for Balaghah Testing (JSU of UPBal).

\section{CONCLUSION}

Developing an instrument model for Balaghah Testing at the Malaysian Higher Learning (UPBal) is hoped to become the compass of reference at improving the process of teaching and learning Balaghah and Arabic language at the higher learning institution. When the Balaghah education at the higher learning institution achieves its expected purpose and objectives, it is hoped that truly learned students who are with thorough comprehension and the ability to appreciate the secrets of aesthetics and mearning in the Holy Quranic verses, along with the ability to apply it in life. This effort is hoped to become the initiating point towards building a new landscape in the teaching and learning Balaghah in Malaysia.

\section{ACKNOWLEGEMENTS}

This research paper is part of a PhD study in National University of Malaysia (UKM). The studies sponsored by Universiti Sultan Zainal Abidin (UniSZA) and Ministry of Higher Education in Malaysia.

\section{REFERENCES}

Al-Quran.

Abdul Aziz Mu'thi Arafah. 2001. Min Balaghat an-Nazm al-Qura'ni (dirasah wa tahlil li masaail ilmi al-maa'ni). Kaherah: Universiti al-Azhar.

Abdul Hakim Abdullah. 2003. Pengajaran Balaghah di peringkat STPM di Sekolah Menengah Kebangsaan Agama (SMKA): Pelaksanaan dan permasalahannya, Ph.D Thesis, Universiti Kebangsaan Malaysia.

Abdul Hakim Abdullah. 2008. Pengalaman dan Hala Tuju Pengajaran Bahasa dan Kesusasteraan Arab di Universiti Darul Iman Malaysia. Bangi: Universiti Kebangsaan Malaysia UP.

Abdul Hakim Abdullah. 2008. Pengajaran Balaghah di peringkat STPM di Sekolah Menengah Kebangsaan Agama (SMKA), Jurnal Islam dan Masyarakat Kontemporari, Jilid 1, Fakulti Pengajian Kontemporari Islam, Universiti Sultan Zainal Abidin, Terengganu.

Abdullah Tahmim. 1999. Pengajaran Balaghah di Sekolah dan Pusat Pengajian Tinggi, Prosiding Seminar Balaghah (Retorika) Arab - Melayu, Universiti Kebangsaan Malaysia, hlm. 33-41.

Ab. Rahim Hj. Ismail. 1999. Taalim al-Balaghah al-Arabiyyah fi Kuliyyah al-Dirasat alIslamiyyah. Prosiding Seminar Balaghah (Retorika) Arab - Melayu, Universiti Kebangsaan Malaysia, hlm. 185-194.

Abd. Rahman Abd. Ali al-Hasyimi. 2005. Tadris al-Balaghah al-Arabiyyah. First Edition, Amman: Dar al- Massira. 
Abdul Rahman Abdullah. (t.trh). Mendalami Bahasa Arab (ilmu Balaghah), Pustaka Ilmi, Malaysia.

Abd al-Qahir al-Jurjaniy. 2002. Dala'il al-I'jaz Fi al-Ilm al-Ma'ani, Beirut: al-Maktabah alasriyyah.

Ali Ahmad Madkur 2010. Turuq Tadris al-Lughoh al-Arabiyyah, Amman: Dar al-Masira.

Almuslim Mustafa, Zamri 2015. Penentuan Dimensi Kualiti Guru Bahasa Arab di Malaysia, Jurnal Islamiyyat 37 (1) 2015: 49 -57.

Azhar Muhammad, Abdul Hafiz Abdullah, Bushrah Basiron, Kamarul Azmi Jasmi \& Sulaiman Shakib. 2006. Penguasaan Pelajar Sekolah Menengah Aliran Agama Terhadap Pengajian Ilmu Retorik Arab (Balaghah). Research Report, Centre for Islamic Studies and Social Development, Universiti Teknologi Malaysia.

Azhar Muhammad. 2006. Pembelajaran Balaghah Arab di peringkat Sijil Tinggi Agama Malaysia: Satu kajian kes, Phd Thesis, Universiti Malaya.

Azhar Muhammad. 2007. Menterjemah budaya retorika Melayu melalui pelaksanaan pengajaran ilmu Balaghah Arab dalam kalangan pelajar Melayu, Kuala Lumpur: Koleksi Persidangan Penterjemahan Antarabangsa (Ke-11: 21-23 Nov 2007.

Azhar Muhammad. 2008. Pendidikan Balaghah Arab di Malaysia, Skudai: Penerbit Universiti Teknologi Malaysia.

Azizi Ahmad, and Mohd Isha Awang 2008. Pengukuran dan Penilaian Pendidikan, Dewan Bahasa dan Pustaka, Kuala Lumpur.

Azrilah Abdul Aziz, Mohd Saidfudin Masodi and Azami Zaharim 2015. Asas Model Pengukuran Rasch, Bangi: Penerbit Universiti Kebangsaan Malaysia.

Badri Najib Zubir. 2002. Balaghah as an Instrument of Quran Interpretation: A Study of alKassyaf, International Islamic Universiti of Malaysia.

Bachman. 1990. Fundamental Consideration in Language Testing. Oxford University Press, New York.

David R.Krathwohl. 2002. A Revision of Bloom's Taxonomy An Overview, College of Education, Ohio State University.

Falah Soleh Hussin al-Jaburi. 2015. Toro'iq Tadris al-Lughah al-Arabiyyah Fi Dhow'I Ma'ayir al-Jaudahas-Syamilah, Dar al-Redhwan, Amman.

Fathi Farid. 1983. Al-Hadaf Min Dirasah al-Balaghah. Al-Azhar. Feb- Mac, hlmn 735-742.

Ghazali Darussalam, and Sufean Hussin (2016) Metodologi Penyelidikan dalam Pendidikan, Kuala Lumpur: Penerbit Universiti Malaya.

Hamid Adam Thuwaini (2007). Al-Balaghah al-Arabiyah : al-Mafhum wa al-Tatbiq, Amman: Dar al-Manahej.

Hassan Basri Awang Mat Dahan. 2012. Language Testing: The Construction and Validatian. Kuala Lumpur: Penerbit Universiti Malaya.

Hassan Shahatah. 1993. Taalim al-Lughah al-Arabiyyah Baina an-Nazariyyat wa at-Tatbiq, Kaherah: Dar al-Lubnaniyyah al-Mesriah.

H. Douglas Brown. 2010. Second Edition, Language Assessment; Principles and Classroom Practices, Pearson Education Longman, United States of America.

Hussein Abdul-Raof. 2006. Arabic Rhetoric (a pragmatic analysis), Routledge (Taylor and Francis Group), New York.

Ibnu Manzur Al-Afriqi. 2003. Lisanul Arab. Dar Sader, Beirut Lubnan.

Idris Abdullah, Abdul Hakim Abdullah, Abdul Wahid Salleh, and Zulazhan Abdul Halim. 2012. Ilmu Balaghah dan Pembentukan Keupayaan Bahasa Arab, Pustaka Darul Bayan, Selangor.

In'am Fawwal Akkawi. 1996. Mu'jam Mufassal Fi Ulum al-Balaghat, Darul Kutub alIlmiyyah, Lubnan. 
Imran Jasim al-Jaburi, and Hamzah Hashim al-Sultoni. 2013. al-Manahij wa Toro'iq Tadris alLughoh al-Arabiyyah, Dar al-Redhwan wa Muassasah Dar as-Sodiq, Amman.

Ismail Ibrahim. 1994. Pengajian dan Pembelajaran Bahasa Arab di Sekolah-sekolah dan Pusat Pengajian Tinggi Malaysia. Dlm Abdul Halim el-Muhammady (Pnyt). Pendidikan Islam dalam Pembangunan Ummah. Kuala Lumpur: Budaya Ilmu Sdn. Bhd.

Kamarul Syukri Mat Teh, Zulazhan Abdul Halim, Mohd Shahrizal Nasir, and Nurazan Mohmad Rouyan. (2012). Dinamika dalam Menelusuri Profesional Keguruan, Penerbit Universiti Sultan Zainal Abidin (UniSZA).

Kamus Dewan. Edisi Keempat (2009). Dewan Bahasa dan Pustaka, Kementerian Pendidikan Malaysia, Kuala Lumpur.

Kaseh Abu Bakar. 2008. Rasch Calibration of Arabic Reading Diagnostic Test Items. PhD Thesis, International Islamic University Malaysia.

Mat Taib Pa. 2008. Isu-isu Pengajaran Bahasa dan Kesusasteraan Arab di Institusi Pengajian Tinggi. Prosiding Seminar Pengajaran Bahasa dan Kesusasteraan Arab di Institusi Pengajian Tinggi Malaysia. Jabatan Bahasa Arab dan Tamadun Islam, FPI UKM.

M. Hafizuddin dan Kamarul Syukri. 2016. Kaedah Pengajaran Tatabahasa Arab, Dalam Aznida Aziz etl, Isu Pendidikan Bahasa Arab Aspirasi Guru-Autonomi Pelajar, Penerbit UniSZA Kuala Terengganu, Malaysia.

Mohamad Najib Abdul Ghafar. 2011. Edisi Kedua. Pembinaan dan Analisis Ujian Bilik Darjah, Skudai: Universiti Teknologi Malaysia.

Mohamad Sahari Nordin. 2005. Pengujian dan Penaksiran di Bilik Darjah, Research Centre, International Islamic University Malaysia.

Mohsin Ali Atiyyah. 2006. Al-Kafi fi Asaalib Tadris al-Lughoh al-Arabiyyah, Dar al-Syuruq, Amman-Jordan.

Mohsin Ali Atiyyah. 2007. Tadris al-Lughoh al-Arabiyyah Fii Dhow'I al-Kifayat alAda'iyyah, Dar al-Manahej, Amman-Jordan.

Mok Soon Sang (2009), Pedagogi Untuk Pengajaran dan Pembelajaran, Penerbitan Multimedia Sdn. Bhd, Puchong Selangor.

Nasr Eldin Ibrahim Ahmad. 2005. Wujuuh al-I'jaz fi al-Khitob al-Usluubi wa al-Ma'rifi li alQuran al-Karim. IIUM Press.

Noraini Idris, and Shuki Osman. 2009. Pengajaran dan Pembelajaran (Teori dan Praktis), Dlm Norasmah Othman, Shuki Osman, Kaedah Pengajaran dan Pembelajaran. McGraw Hill Education, Malaysia.

Nor Aisyah Buang. 2010. Tinjauan Literatur. Dalam Noraini Idris. Penyelidikan dalam Pendidikan, McGraw Hill Education, Malaysia.

Osman Khalid. 1994. Pengajian dan Pembelajaran Bahasa Arab di Sekolah-sekolah dan Pusat Pengajian Tinggi Malaysia. Dlm Abdul Halim el-Muhammady (Pnyt). Pendidikan Islam dalam Pembangunan Ummah. Kuala Lumpur: Budaya Ilmu Sdn. Bhd.

Raja Hazirah Raja Sulaiman. 2012. Penguasaan Balaghah Dalam Kalangan Pelajar IPT, Tesis Sarjana, Universiti Malaya, Kuala Lumpur, Malaysia.

Ratib Qasim Asyur, and Mohamad Fuad al-Hawamidah. 2009. Funun al-Lughoh al-Arabiyyah wa Asaalib Tadrisiha, Alimul Kutub al-Hadis, Irbid-Jordan.

Robert L.Linn, and Norman E.Gronlund. 2000. Eight Edition Measurement and Assessment in Teaching, Pearson Education, New Jersey.

Siti Rahayah Ariffin. 2003. Teori, Konsep \& Amalan Dalam Pengukuran dan Penilaian, Pusat Pembangunan Akademik, Universiti Kebangsaan Malaysia.

Shuhaida Hanim Mohamad Suhane et al. 2017. Kepentingan Pembinaan Model Strategi Pengajaran dan Pembelajaran Balaghah peringkat Institut Pengajian Tinggi di Malaysia, dalam "Penataran Pendidikan Bahasa Arab di Peringkat Pengajian Tinggi", Penerbit Universiti Sultan Zainal Abidin (UniSZA), Terengganu. 
Rosni Samah. 2009. Isu Pembelajaran Bahasa Arab di Malaysia, Penerbit Universiti Sains Islam Malaysia.

Talib Mohamad Zuba'I and Nasir Halawi. 1996. Al-Bayan wa al-Badi' Li Tolabah Qism alLughah al-Arabiah, Dar an-Nahdhah al-Arabiah, Beirut.

Thomas H. Buxton, and Keith W. Prichard. 1975. Excellence in University Teaching, Universiti of South Carolina Press, Columbia, S.C.

Walid Ahmad Jabir. 2002. Tadris al-Lughoh al-Arabiyyah Mafaahim wa Nazariyyah wa Tatbiqat Amaliah, Dar al-Fikr li Tiba'ah, Amman Jordan.

Zulazhan bin Ab. Halim. 2012. Kebolehbacaan buku teks balaghah Sijil Tinggi Agama Malaysia di sekolah-sekolah menengah Agama Negeri, Tesis Ph.D, Universiti Kebangsaan Malaysia.

Zulazhan Ab. Halim, Mohd Ala-uddin Othman. Mohd Hazli bin Yah@Alias, Shuhaida Hanim binti Mohamad Suhane, and Abdul Wahid bin Salleh. 2013. Kebolehbacaan Buku alBalaghah al-Wadihah Dalam Kalangan Pelajar Institusi Pengajian Tinggi Pantai Timur, Laporan Penyelidikan, Fakulti Bahasa dan Komunikasi, Universiti Sultan Zainal Abidin.

\section{SHUHAIDA HANIM MOHAMAD SUHANE}

Pusat Pengajian Bahasa Arab,

Fakulti Bahasa dan Komunikasi,

Universiti Sultan Zainal Abidin (UniSZA)

KASEH ABU BAKAR

Pusat Kajian Bahasa Arab dan Tamadun Islam

Fakulti Pengajian Islam

Universiti Kebangsaan Malaysia (UKM)

MD NOR ABDULLAH

Pusat Kajian Bahasa Arab dan Tamadun Islam

Fakulti Pengajian Islam

Universiti Kebangsaan Malaysia (UKM)

*Pengarang untuk surat menyurat: shuhaida@unisza.edu.my

Received: 10 September 2021 / Accepted 22 October 2021 / Published: 20 November 2021 